\title{
Pushy parents make for later grandparents: parents' educational expectations and their children's fertility among two British cohorts
}

\author{
Dylan Kneale \\ Institute of Education, London \\ D.Kneale@ioe.ac.uk
}

(Received 30 June 2009 Revised November 2009)

\section{Abstract}

The timing of first birth is often viewed through the opportunity costs of childbearing theory - greater potential in the labour market will lead to postponement of first birth. This paper examines the effect of parental educational expectations in shaping opportunity costs as predictors of early parenthood, using data from two British Birth cohorts born in 1958 and 1970. Rapid inter-cohort changes in labour market and educational patterns could change the importance of educational expectations in determining time to first parenthood. Two definitions of early parenthood are used - one relative, based upon the first quartile of each cohort entering parenthood, and the second equating to teenage parenthood. Parental educational expectations measured at age 16 are used in binary logistic regression models for men and women. Predicted probabilities are presented to emphasise the contrast between educational expectations and socioeconomic measures. Parental educational expectations are found to be strong predictors of early fertility in most models. Expecting any post-compulsory education leads to a decrease in the odds of early parenthood against a battery of controls. Where the expectations of parents are non-significant, those of the teacher are significant. Only in the 1970 cohort teenage fatherhood model were educational expectations of important adults found to be non-significant. Adult, usually parental, high educational expectations reduce the probability of young people becoming early parents, even in the presence of controlling factors that are usually assumed to account for this relationship. This indicates a role for parents in future interventions aimed at lowering levels of early parenthood.

\section{Introduction and Literature Review}

Britain's fertility patterns are notable both in the high level of early parenthood (UNICEF 2007) and the socio-economic polarisation in the timing of first birth (Ekert-Jaffe, Joshi et al. 2002; Rendall, Couet et al. 2005). While the majority postpone parenthood, early parenthood remains a norm for a minority (Hadfield, Rudoe et al. 2007). Early parenthood is associated with a range of negative antecedent characteristics and outcomes, evidenced through a large body of research, and became a policy focus for the new millennium (see Social Exclusion Unit 1999). Early parenthood is 
strongly linked to a lack of opportunities and is particularly associated with educational disadvantage. This paper examines the additional role that parental educational expectations play in governing who becomes an early parent.

Establishing a greater understanding of the factors that predict entry into parenthood is not only a valuable target in itself, but may help clarify whether young age is responsible for the negative outcomes associated with early parenthood (Furstenberg 2007). This paper explores how parental educational expectations predict entry into early parenthood as opposed to pregnancy, the sole link being that pregnancy is a necessary condition for parenthood. This paper examines who becomes a mother or a father early in two British birth cohorts (1958 and 1970 born) using both a teenage definition of early parenthood as well as a more relative definition of 'early'. This is in response to the relative rarity of occurrences of teenage parenthood, the fact that giving birth in the early and mid-twenties has been shown to carry negative effects (Hobcraft and Kiernan 2001; Robson and Berthoud 2006), and the need to understand patterns of early parenthood in an apolitical and contextually appropriate way for both men and women (Geronimus 2003; Duncan 2007; Furstenberg 2007; Kneale 2009a). Here, parental educational expectations are found to be potent predictors of early parenthood varying by gender, cohort and definition of early.

This paper begins by reviewing some of the literature that hypothesises that opportunity costs of childbearing are a mechanism for governing the timing of parenthood. The data and methodology used to analyse the effect of parental educational expectations are then presented. Finally the potency of parental educational expectations, relative to other predictors of early parenthood, is examined before giving further consideration to the results.

\section{Opportunity Costs, Expectations and the Timing of Parenthood}

Explanations for the timing of (early) motherhood are often based upon the theory concerning opportunity cost of childbearing. The theory states that women who face the highest levels of wage penalties and missed chances for career progression through taking time out of the labour market for motherhood (opportunity costs) will delay this process the most (Becker 1991; Joshi 1998; Joshi 2002). Education is a key marker of labour market success, and a lack of education is found to propel young women towards early motherhood (Hobcraft \& Kiernan, 2001). Several studies have consistently found the link between higher educational levels and delayed parenthood (for example Kiernan 1997; Rendall and Smallwood 2003; Lappegard and Ronsen 2005; Rendall, Couet et al. 2005; Smith and Ratcliffe 2009). Data from the British birth cohort studies, two of which are used in this paper, suggest that the increasing age at first parenthood of women, is strongly associated with the increase in those attaining tertiary qualifications (Ferri and Smith 2003). For men, explaining the link between low education and early fertility is more challenging, although assortative mating based on educational characteristics is an often-cited mechanism (Hynes, Joyner et al. 2008), thereby indirectly implicating the opportunity cost hypothesis. Education is not the only predictor of labour market success; other factors such as socioeconomic circumstances, family structure and behavioural characteristics are also influential, and in turn influence the timing of fertility. Beyond opportunity cost theory, theories of early parenthood based on social exclusion have also gained prominence whereby the norms and values of socially excluded people become detached from those of the socially included (Burchardt, Le Grande et al. 2002), including family building and fertility norms (for example Kiernan 1997; Arai 2003).

This present paper aims to show that these norms may stretch to the way in which education is perceived, and that only in the presence of both high educational expectations and high educational ability, will the highest chance of avoiding early parenthood be achieved. Therefore, while it is not disputed that the idea of highly qualified and/or advantaged people have more incentive to avoid early parenthood through having higher opportunity costs, this paper explores whether educational ability is the sole component of this calculation.

Calculating the opportunity cost of having children implies a substantial degree of planning (Joshi 1998; Gustafsson 2001). While educational achievement and socio-economic background undoubtedly influence these plans, early motherhood is not a predestined outcome even for those from disadvantaged backgrounds, of which a 
substantial group avoid early parenthood. Equally, advantage is not always associated with avoiding early parenthood. Qualitative studies find that family-building expectations and notions of 'successful adulthood' are crucial in determining who enters parenthood early, and success for some young people is not measured through career progression (Arai 2003; Kendall, Afable-Munsuz et al. 2005; Harden, Brunton et al. 2006; Arai 2007). An expectation of starting a family early, which is often incompatible with being a student (Edwards 2002; Joshi 2002), may mean that educational expectations are consequently lowered. Conversely, high educational expectations may increase the perceived opportunity cost of having a child, even if these expectations do not correlate with educational ability. For men, assortative mating based on educational characteristics is expected to be the main mechanism through which educational expectations predict early fatherhood (for example Becker 1991; Qian 1998; Sweeny and Cancian 2004). Men may also not want to be 'burdened' with beginning a family early if they are to attain the high expectations of their parents.

\section{Educational Expectations}

The home learning environment has long been linked with children's outcomes. Douglas (1964) found in the first national birth cohort study of children born in 1946 that the most important driver of educational progress was the amount of interest shown by parents in their children's education. Using the same data, Kiernan and Diamond (1983) showed that parental interest in education was also a predictor of the timing of first parenthood. For later cohorts, opportunities for educational achievement changed, with huge growth in the availability of further and higher education (Makepeace, Dolton et al. 2003). Nevertheless, links between parental interest in education and children's educational success (Flouri 2006; Feinstein, Duckworth et al. 2008), and children's subsequent fertility patterns (Kiernan 1997; Russell 2002), remain. This paper examines components of the learning environment that have a closer connection to calculating opportunity costs through focusing on educational expectations; in other words the expectation of leaving education at the minimum age, progressing to further education or progressing to higher education. Parents' expectations, as opposed to those of the child, are the focus, as parents provide the economic and social resources available to children (Morrison Gutman and Akerman 2008), and young adults (Schoeni and Ross 2004) to help realise these expectations.

Educational 'expectations' and 'aspirations' are often used interchangeably in the literature (Flouri and Hawkes 2008). While there may be overlap, with expectations having a significant aspirational component, they do differ (Goldenberg, Gallimore et al. 2001; Lupton and Kintrea 2008). Despite current policy being orientated towards examining aspirations (Cabinet Office 2008; Morrison Gutman and Akerman 2008), here, the focus is on expectations because of their closer alignment to life course planning. Parental expectations may be statements of intent that indicate support for the child in a way not captured by aspirations alone. Additionally, children are more likely to be aware of their parents' expectations; parents' true aspirations for their children may not be known by their children. While educational expectations are likely to reflect current behaviour in part, their collection from parents (generally before young people leave school) in this study means that they also capture a strong predictive component (Schoon 2010). The differing expectations of parents, teachers and children (Schoon forthcoming 2010), suggests that, in addition to reflecting current behaviour, expectations also capture influences on future behaviour.

Educational expectations have been found to be significant predictors of educational attainment and occupational success in several studies, including those using the same data used in this paper (Bond and Saunders 1999; Flouri and Hawkes 2008; Goyette 2008; Reynolds and Woodham Burge 2008). Parental educational expectations may influence educational and occupational attainment through their influence on children's expectations (Flouri and Hawkes 2008). They may also indicate family resilience to external factors (Schoon 2006). Social class and ability are determinants of aspirations and expectations, with lower socioeconomic status correlating with lower expectations (Casanova, García-Linares et al. 2005; Feinstein, Duckworth et al. 2008; Goyette 2008), but the potency of expectations may be greater among lower socio-economic groups (Casanova, García-Linares et al. 2005; Schoon 2006).

Gender also plays a role in determining expectations (Schoon 2006; Schoon, Martin et al. 
2007; Morrison Gutman and Akerman 2008). Expectations for girls are argued to be more important than those for boys, if girls are to break away from traditional gender role stereotypes (Flouri and Hawkes 2008). But while the links between expectations and educational attainment appear solid, less is known about the links between educational expectations, life course planning and fertility. In the United States, studies that have examined this quantitatively (for example Driscoll, Sugland et al. 2005), have not been able to quantify the effect described in qualitative US and UK studies (Arai 2003; Kendall, Afable-Munsuz et al. 2005; Harden, Brunton et al. 2006). Schoon and colleagues' UK study did find evidence of a link between parenthood and parental educational expectations for both men and women using British birth cohort data (Schoon, Martin et al. 2007). However, that study, using path analysis, was focussed on adult occupational status and not parenthood as the main outcome, and therefore omitted some key controlling factors from models. Furthermore, that study examined parenthood at any point and not only early parenthood, and did not disaggregate the effects of parental educational expectations, treating these instead as binary measures.

While Schoon and colleagues' study gives a basis for looking at parental educational expectations, particularly as predictors of occupational success, this present study shows how parental educational expectations predict early parenthood for men and women in two cohorts using two definitions of 'early' against a battery of controlling factors significant in the literature. It also presents results showing the potency of these expectations relative to the expectations of others and relative to other socioeconomic factors. The methodology allows for a clear indication of the nuances of different levels of educational expectations on early parenthood, and will also explore whether expectations have a greater impact on women and on those from more disadvantaged families. Ferri and Smith (2003) speculate that the impact of career development for women and increased alternatives to family life has grown over time, and that recent rises in age at first parenthood across the British birth cohort studies are unlikely to be solely a product of rising levels of tertiary educated women. Based upon that argument, it might be expected that the influence of educational expectations will have grown over time as female labour market participation has increased; by examining two cohorts, this issue is addressed, and inferences drawn on how the impact has changed over time by gender.

The underlying hypothesis investigated here is that parental educational expectations will independently moderate entry to early parenthood, even after controlling for components that usually form the calculus of opportunity costs. The specific hypotheses are:

a) Parental educational expectations have a greater impact for predicting entry to parenthood for women than men, possibly as indicators for non-traditional gender roles which involve later motherhood.

b) Parental educational expectations have a greater impact on early parenthood than those of other actors, as they provide an indication of the learning environment as well as influencing the cohort member's own expectations.

c) Parental educational expectations will have an increasing effect across the twelve years that separate the two birth cohort studies, because of their increased influence in relation to female children

\section{Data, Measurements and Methodology}

\section{Data}

This paper uses data from two prospective national British birth cohort studies - the National Child Development Study (NCDS) and the British Birth Cohort Survey (BCS70) that track individuals born within a week in 1958 and 1970 respectively. Over 18,000 have been involved in each study at some point (see Elliott and Shepherd 2006; Power and Elliott 2006; Bynner and Joshi 2007 for more information). Since birth, data collection has occurred at ages $7,11,16,23,33,42$ and 46 for the NCDS; for the BCS70 at ages 5, 10, 16, 26, 30 and 34 years, with fertility information collected at all post16 sweeps in both cohorts with the exception of age 26 years in the BCS70. These fertility histories were consolidated and form the basis of the analyses in this paper (see Kneale 2009b for further information). Despite being born twelve years apart, both cohorts have lived through very different contexts relevant to this paper, including 
rises in age at first parenthood (Ferri and Smith 2003), growth in further and higher education (Makepeace, Dolton et al. 2003) and increasing educational expectations (Schoon 2010). Both studies originally constituted a British census of births born in these weeks, although through attrition, may not remain wholly representative (see Plewis, Calderwood et al. 2004 for details on attrition over time). There is also concern that the birth histories, and particularly BCS70 histories that were only first collected at age 30 years, may under-represent the number of teenage parents. However, analyses of cohort birth histories compared with official statistics, show that these cohort studies have remained generally representative with respect to first motherhood (Kneale and Joshi 2008).

\section{Measures}

Early Parenthood: In addition to a teenage definition, this paper uses a more contextually normative and apolitical definition of 'early' parenthood which distinguishes the first quartile of males and females of each cohort to become parents (derived from Kaplan-Meier Event History models). This definition, referred to as 'early' as opposed to 'teenage' from this point, is a response to the relative rarity of teenage parenthood and the fact that negative effects from early parenthood extends to giving birth in the early-mid twenties (Hobcraft and Kiernan 2001). Table 1 shows the corresponding ages at which the first quartile is reached, with the proportions of teenage parents (under 20 years).

Table 1: Age at which the first quartile of entry into parenthood is reached and proportion of teenage parents by cohort and gender

\begin{tabular}{lcccc}
\hline & \multicolumn{2}{c}{ Age at first quartile } & \multicolumn{2}{c}{ Proportion of teenage parents } \\
& $\delta$ & + & 0 & + \\
NCDS & 24.95 years & 22.19 years & $3.9 \%$ & $12.8 \%$ \\
BCS70 & 26.99 years & 23.87 years & $3.0 \%$ & $9.8 \%$ \\
\hline
\end{tabular}

This paper examines live births reported by cohort members excluding stillbirths and other fertility outcomes. Those still pregnant or who have fathered a pregnancy not carried to full term are excluded because of problems associated with the accuracy of reports of adverse fertility events (Smith, Adler et al. 1999), as are, inevitably, births which were not reported. This is more likely to be problematic for males for reasons of attrition, because of their potential lack of knowledge of paternity status, and deliberate underreporting of absent children (Rendall, Clarke et al. 1999; Greene and Biddlecom 2000). However, this paper treats these concerns as caveats of the results, as opposed to a proscription from using male fertility histories.

\section{Parental Educational Expectations (Age 16):}

These are grouped into four categories - leaving school at the minimum age, leaving school at 18 entering higher education and being uncertain about future educational trajectories. For the BCS70, an additional category is constructed (see Missing Data below). Educational expectations reports were collected from the main respondent, who was the cohort member's mother in over $90 \%$ of cases. These analyses implicitly assume that the expectations of both parents are similar, an assumption also made elsewhere in the literature (Schoon 2010).

\section{Controlling Factors}

Socio-economic Factors: Socially disadvantaged backgrounds including having a father in a manual social class (Ermisch and Pevalin 2003), living in social housing (Hawkes, Joshi et al. 2004), and living on state benefits (Harden, Brunton et al. 2006) are predictive of early parenthood. The classifications of housing tenure and social class were based on the number of observations in which a cohort member was observed in the particular state, a strategy used in other analyses (Hobcraft and Kiernan 2001; Sigle-Rushton 2005; Hobcraft 2008). Social class was divided into those whose fathers were always in the most advantaged group, were sometimes in the most advantaged group or were never in the most advantaged group (the latter also includes those always without a father). The most advantaged group differs slightly in definition 
between cohorts as relying on a non-manual definition of advantaged alone would see a large rise in those being categorised as advantaged. Tenure was classified by experience of social housing, owner occupied housing or private/other housing. The classification strategy for social class and tenure gives a broader indication of childhood environment as well as serving to minimise the effect of missing data, essentially constituting a form of imputation (see Kneale 2009b for more information). Receipt of state benefits indicates those (at age 16) whose family income was obtained wholly or in part from unemployment or sickness benefits.

Educational Measures: Generally, reading and maths ability were tested at all points (through differing tests), with other abilities tested intermittently (see Feinstein, Duckworth et al. 2008 for one outline, pp147-151). For the BCS70, due to a teacher's strike at age 16, a high number of tests were not administered (Goodman and Butler 2005). Additionally, at the time of analysis, maths and reading ability at age 16 were unavailable. Instead, for the BCS70, maths and reading ability at age 10 years were tested. Preliminary analyses also showed that English Vocabulary Picture Test Score (EVPT) from age 5 was also significant (see Golding 1975 for test description). All ability measures were transformed into quartiles, and treated as categorical variables. Other educational measures used, including dislike of school and truancy/school attendance, were collected from cohort members at age 16 and classified as categorical variables, with the exception of attendance from the NCDS, which is modelled continuously as the proportion of lessons missed. Teachers' educational expectations for cohort members (NCDS only) and the cohort members' own educational expectations were also tested. Both were also measured at age 16, and while they correlated with the expectations of the parents, this did not introduce multicollinearity.

Behavioural and Philoprogenitive Measures: Among both cohorts, parents completed a psychometric questionnaire on their child's behaviour based upon Rutter's behavioural score inventory at age 16 (Rutter 1967). Using Principle Components Analysis separately for boys and girls, generally resulted in three main components for both cohorts. Here, the disruptive and aggressive score at age 16 was most significant, and was divided into quartiles and treated as categorical. Philoprogenitive tendencies were measured differently between cohorts. For the NCDS, they were measured as the ideal age at which the cohort member wanted to become a parent, collected at age 16 . For the BCS70 they were measured as the importance to a cohort member of having their own family by age 16 .

Home Learning Environment and Demographic Measures: Family structure at age 16 and age of the cohort member's mother at birth are significant predictors in the literature and are included in these analyses (Kiernan and Cherlin 1999; Meade, Kershaw et al. 2008). For the NCDS, parenting style at age 16 was included, and comprised an additive score based on a series of statements from the cohort member on how disciplinarian they viewed their parents; a similar score for BCS70 based on cohort member reports on their relationship with their parents was also created. Finally, teachers were asked to rate their perception of how interested the parents of cohort members were, in their children's education. For both cohorts, this represented the mother's interest, although for the BCS70 this was measured at age 10 and for NCDS at age 16 years'. Because of the small numbers, parents who were deemed uninterested or 'overinterested' were grouped together as having 'unhealthy' levels of interest.

The inclusion of these variables as controls in models is based upon their significance in early parenthood literature, where for example, Harden (2006) and Imamura (2007) represent recent systematic reviews of the antecedent factors surrounding early pregnancy, while Hobcraft (2008), Kiernan (1997), Hobcraft and Kiernan (2001) and Sigle-Rushton (2005) all represent studies that have used the same data and included several of the controls presented here.

\section{Missing Data}

In this paper list-wise deletion alone was not considered suitable because of the effect it had on sample sizes. Other strategies considered including weighting the data and using multiple imputation techniques (see Goldstein 2009 for an example using cohort data). Exploiting observations from previous waves was used to derive social class and housing tenure variables. For variables measured once, or where this was not a suitable strategy, an item non-response category was created and modelled. This was the strategy taken when over $25 \%$ of observations were missing, which was generally the case for several 
controlling factors in the BCS70 age 16 sweep. Although that sweep recorded a response rate of $70.6 \%$ with 11,206 responses recorded (Plewis, Calderwood et al. 2004), it was split into twelve questionnaires and not all parts were completed; those collected in school recorded particularly low response due to a concurrent teachers' strike. Modelling the missing category is a frequently-used strategy to ensure preservation of sample size, and allow comparisons between the missing and baseline groups (for example Mensah and Hobcraft 2008).

\section{Methodology and Model Construction}

This study estimates the probability of becoming an early parent (according to the earlier definitions) versus not becoming an early parent after accounting for a number of known predictors. Binary logistic regression models are used and the results presented as odds ratios. An odds ratio above one indicates that the probability of becoming an early parent is greater among a particular group than the baseline group, or in the case of continuous predictors, that the probability of becoming an early parent increases with a one unit increase in the covariate. An odds ratio below one indicates the opposite, while an odds ratio of exactly one indicates no difference between groups. HosmerLemeshow tests were also conducted to assess the overall goodness-of-fit of the models - these test whether the models that have been constructed deviate significantly from the actual observed data - in no case was this found to be the case ${ }^{i i}$. All covariates were tested for multicollinearity - this was not found to be problematic.

A number of the predictors used in these analyses were measured at age 16. Although reverse causality is unlikely, as a cautionary measure, the small number of cohort members who became parents before age 17.5 years were excluded. Models with 'all' early parents and those where the 'clock began ticking' at 17.5 years showed the exact same trends; only those with the restriction are presented here. Consequently, 28 young fathers and 96 young mothers were excluded in the
BSC70, and 44 and 187 young fathers and mothers from the NCDS. An alternative approach could have examined measurements from earlier time points, and crucially for this analysis, parental educational expectations measured at 10/11 years for the BCS70 and NCDS respectively. However, that option was not favoured, as other factors that might be regarded as confounding factors, such as philoprogenitive tendencies and the cohort member's own educational expectations, could not be adequately controlled for from this period. Additionally it may be questionable to bring in notions of life course planning at such a young age.

\section{Results}

\section{Descriptive Information}

Table 2 shows descriptive information for all variables included in the models. Of those who gave a definitive answer, $46 \%$ in NCDS and $62 \%$ in BCS70 expected their child to continue in further education. However, this was more likely to be capped at 18 for the BCS70 cohort higher education (post-18) was a more frequent expectation for the NCDS cohort. In both cohorts more girls than boys were expected to remain in postcompulsory education. However, the gender bias disappeared after this point as similar proportions of girls and boys were expected to enter higher education. Other changes between cohorts include a decrease in reliance on social housing, in line with known trends that include the 'right to buy' scheme (Lupton, Tunstall et al. 2009), and a slight decrease from $13 \%$ of the cohort in NCDS to $10 \%$ in the BCS70 in family reliance on unemployment and sickness benefits. There was also a growth in fathers in non-manual occupations. Between cohorts, there was also a small drop in the proportion living with both natural parents from $86 \%$ to $84 \%$. The overall picture between cohorts is of decreasing housing and income disadvantage which is consistent with other sources (see Ferri, Bynner et al. 2003 for a review of inter-cohort differences in other domains). 
Table 2: Descriptive Information for all variables tested in models

\begin{tabular}{|c|c|c|c|c|}
\hline \multirow{2}{*}{ Gender } & \multicolumn{2}{|c|}{ NCDS } & \multicolumn{2}{|c|}{ BCS70 } \\
\hline & Male & $48.4 \%$ & Male & $47.5 \%$ \\
\hline & Female & $51.6 \%$ & Female & $52.5 \%$ \\
\hline Parent's Educational & Leave at Min Age & $48.6 \%$ & Leave at Min Age & $26.9 \%(31.6 \%)$ \\
\hline \multirow[t]{3}{*}{ Expectations Age 16} & Stay up to 18 & $19.8 \%$ & Stay up to 18 & $28.5 \%(33.4 \%)$ \\
\hline & Higher Education & $26.1 \%$ & Higher Education & $15.5 \%(18.3 \%)$ \\
\hline & Uncertain & $5.5 \%$ & $\begin{array}{l}\text { Uncertain } \\
\text { Missing }\end{array}$ & $\begin{array}{l}14.1 \%(16.6 \%) \\
15.0 \%\end{array}$ \\
\hline Teacher's Educational & Leave at Min Age & $40.4 \%$ & & \\
\hline \multirow[t]{3}{*}{ Expectations Age 16} & Stay up to 18 & $24.1 \%$ & & \\
\hline & Higher Education & $21.9 \%$ & $N / A^{1}$ & - \\
\hline & Uncertain & $13.6 \%$ & & \\
\hline Maths Score Age10/16 & Quartiles Age 16 & - & Quartiles Age 10 & - \\
\hline Reading Score Age10/16 & Quartiles Age 16 & - & Quartiles Age 10 & - \\
\hline EVPT Score Age 5 & & - & Quartiles Age 5 & - \\
\hline \multirow{2}{*}{$\begin{array}{l}\text { Truancy/Attendance Age } \\
16\end{array}$} & Attendance (Mean) & $91.3 \%$ & Yes, played truant & $24.7 \%(42.1 \%)$ \\
\hline & & & $\begin{array}{c}\text { No, did not play truant } \\
\text { Missing }\end{array}$ & $\begin{array}{l}33.6 \%(57.9 \%) \\
41.8 \%\end{array}$ \\
\hline \multirow[t]{3}{*}{ School Dislike Age 16} & Strongly dislike school & $28.9 \%$ & Strongly dislike school & $9.4 \%(16.1 \%)$ \\
\hline & Dislike school somewhat & $14.0 \%$ & Dislike school somewhat & $24.6 \%(42.1 \%)$ \\
\hline & Do not dislike school & $57.1 \%$ & $\begin{array}{c}\text { Do not dislike school } \\
\text { Missing }\end{array}$ & $\begin{array}{l}24.5 \%(41.8 \%) \\
41.5 \%\end{array}$ \\
\hline Mother's Education & $\begin{array}{l}\text { Mother Continued in Post- } \\
\text { compulsory Ed }\end{array}$ & $\begin{array}{l}\text { Yes: } 26.7 \% \\
\text { No: } 73.3 \%\end{array}$ & $\begin{array}{l}\text { Mother Continued in } \\
\text { Education after } 16\end{array}$ & $\begin{array}{l}\text { Yes: } 18.0 \% \\
\text { No: } 82.0 \%\end{array}$ \\
\hline Cohort Member's & Leave at Min Age & $60.9 \%$ & Leave at Min Age & $23.8 \%(44.1 \%)$ \\
\hline Educational Expectations & Stay up to 18 & $8.0 \%$ & Stay up to 18 & $15.2 \%(26.3 \%)$ \\
\hline \multirow[t]{3}{*}{ Age 16} & Higher Education & $23.0 \%$ & Higher Education & $16.9 \%(29.2 \%)$ \\
\hline & Uncertain & $8.0 \%$ & Uncertain & $2.0 \%(3.4 \%)$ \\
\hline & & & Missing & $42.2 \%$ \\
\hline Receipt of Unemployment & Yes & $12.5 \%$ & Yes & $9.8 \%$ \\
\hline Benefits Age 16 & No & $87.5 \%$ & No & $90.2 \%$ \\
\hline Father's Social Class & Always in Non-Manual & $13.9 \%$ & Always in Top 2 Classes & $6.2 \%$ \\
\hline \multirow[t]{2}{*}{ During Childhood } & Class & $29.5 \%$ & Sometimes & $35.2 \%$ \\
\hline & $\begin{array}{l}\text { Sometimes } \\
\text { Never in Non-Manual } \\
\text { Class }\end{array}$ & $56.6 \%$ & Never in Top 2 Classes & $58.6 \%$ \\
\hline Housing Tenure During & Always Owner Occupied & $40.5 \%$ & Always Owner Occupied & $57.9 \%$ \\
\hline \multirow[t]{4}{*}{ Childhood } & Owner Occ. \& Social & $14.2 \%$ & Owner Occ. \& Social & $21.6 \%$ \\
\hline & Always Social Housing & $32.8 \%$ & Always Social Housing & $15.0 \%$ \\
\hline & Social Housing \& Other & $5.9 \%$ & Social Housing \& Other & $2.5 \%$ \\
\hline & Other Combination & $6.7 \%$ & Other Combination & $3.0 \%$ \\
\hline Age of Mother at Birth & Mean & 27.5 & Mean & 26.0 \\
\hline \multirow[t]{3}{*}{ Family Structure Age 16} & 2 Natural Parents & $86.6 \%$ & 2 Natural Parents & $83.7 \%$ \\
\hline & Reconstituted Family & $5.3 \%$ & Reconstituted Family & $8.9 \%$ \\
\hline & Lone-parent family & $8.1 \%$ & Lone-parent family & $7.5 \%$ \\
\hline \multirow{7}{*}{$\begin{array}{l}\text { Disruptive/Aggressive } \\
\text { Score Age } 16 \\
\text { Parenting Score Age } 16\end{array}$} & Quartiles Age 16 by & - & Quartiles Age 16 by & - \\
\hline & Index of perceived & & Index of Perceived & \\
\hline & disciplinarian parents: & & Parenting Relationship & \\
\hline & Very Disciplinarian & $20.3 \%$ & Age 16: & $7.0 \%(11.8 \%)$ \\
\hline & Somewhat Disciplinarian & $63.4 \%$ & Mostly Negative & $18.2 \%(30.6 \%)$ \\
\hline & Not Disciplinarian & $16.3 \%$ & Some Positive & $34.3 \%(57.6 \%)$ \\
\hline & & & $\begin{array}{l}\text { Mostly Positive } \\
\text { Missing }\end{array}$ & $40.4 \%$ \\
\hline Mother's Interest in & Healthy Interest & $39.1 \%$ & Healthy Interest & $54.1 \%$ \\
\hline Education (Age 16 NCDS, & Some Interest & $32.3 \%$ & Some Interest & $29.3 \%$ \\
\hline Age 10 BCS70) & Unhealthy Interest & $15.4 \%$ & Unhealthy Interest & $5.5 \%$ \\
\hline & Can't Say/NA & $13.2 \%$ & Can't Say/NA & $11.1 \%$ \\
\hline Philoprogenitive & Ideal Age to Have a Child: & & Importance of Own & \\
\hline Tendencies Age 16 & Under 22 years & $14.3 \%$ & Children & $23.2 \%(44.2 \%)$ \\
\hline & 22 years and above & $85.7 \%$ & Matter Very Much & $20.5 \%(39.1 \%)$ \\
\hline & & & Matter Somewhat & $8.8 \%(16.7 \%)$ \\
\hline & & & Don't Matter & $47.5 \%$ \\
\hline & & & Missing & \\
\hline Region of Residence Age & Eastern & $9.4 \%$ & East & $10.6 \%$ \\
\hline 16 years & Midlands & $9.8 \%$ & East Midlands & $7.8 \%$ \\
\hline & London \& South East & $13.3 \%$ & London & $5.3 \%$ \\
\hline & Northern & $7.7 \%$ & North East & $6.7 \%$ \\
\hline & North Western & $12.0 \%$ & North West & $14.2 \%$ \\
\hline & Southern & $7.2 \%$ & South East & $11.3 \%$ \\
\hline & South Western & $6.8 \%$ & South West & $9.5 \%$ \\
\hline & North Midlands & $7.8 \%$ & West Midlands & $9.0 \%$ \\
\hline & East \& West Riding & $7.3 \%$ & Yorkshire and Humber & $8.6 \%$ \\
\hline & Wales & $5.2 \%$ & Wales & $7.2 \%$ \\
\hline & Scotland & $13.5 \%$ & Scotland \& Other & $9.5 \%$ \\
\hline $\mathbf{N}$ & & 5,355 & & 5,057 \\
\hline
\end{tabular}

'Teacher's Educational Expectations were collected in the BCS70, although very poor data quality prevented their use.

Figures in Brackets represent valid percentages 


\section{Results from Models}

Parental educational expectations were significant predictors of entry into most definitions of early parenthood, although less so for NCDS teenage parenthood and for BCS70 teenage fatherhood (tables 3-4). In the NCDS teenage parenthood models, teachers' educational expectations predicted teenage fertility more than those of the parents; for 'early' parenthood, this was not the case and for the BCS70, teacher expectations were not investigated because of poor response rates. In both cohorts, parents' expectation that their child would go into higher education was more protective against entry into parenthood, than expecting a child to stay in education until 18 years, which in turn was more protective than expecting a child to leave at the minimum school leaving age. Indecision was also found to be protective in some instances.

Life course planning was also related to the cohort members' philoprogenitive tendencies and was significant for all definitions of early motherhood and teenage fatherhood in the NCDS cohort. For the NCDS, wanting a child after 21 years reduced the odds of early motherhood by $28 \%$ and almost 50\% for teenage fatherhood. For the BCS70, attaching a low value on having children in the future reduced the odds of becoming an early mother by $45 \%$ and $57 \%$ for teenage motherhood.

\section{Gender}

The general lack of significance of parental expectations in models of teenage fatherhood could indicate that life course planning may be relatively unimportant. That might be expected if teenage fatherhood models are not capturing forms of 'planned' family formation but rather the characteristics of males having unprotected sex, as has been speculated (Kneale 2009). However, this is refuted somewhat by the fact that teacher educational expectations were significant when modelling NCDS teenage fatherhood. Tests for interactions between gender and parental educational expectations were not significant for either cohort or definition of 'early'. Perhaps parental educational expectations are equally important to men and women in reducing the probability of early parenthood, which would refute the first hypothesis, concerning gender differences.

For NCDS men, (but not women) disciplinarian parenting style was found to be significant, with very disciplinarian parenting associated with higher odds of early fatherhood. For BCS70 women, an index of parenting relationship was a significant predictor of early motherhood, with negative relationships associated with earlier parenthood; there was no such relationship for fatherhood. The difference in measures shows that comparison across cohorts is difficult. In models of data on females, but not in male data, another element of the home learning environment was significant in both cohorts and both definitions of 'early'. Although measured at different time points, having a mother with an 'unhealthy' interest in education approximately doubled the odds of early motherhood relative to having a mother with a 'healthy' interest. This teacher-rated variable reinforces the fact that the home learning environment and parents' involvement in their children's lives moderates transition to early parenthood.

\section{Parental, teacher and cohort member educational expectations}

NCDS teenage parenthood models offer strong evidence for the importance of an adult figure in governing time to parenthood, although they do not indicate that this necessarily has to be the parent. In the BCS70 cohort, where teacher expectation is poor quality data, parental expectations are consistent predictors of entry into most forms of early parenthood. No instance was found, in any model, of cohort members' own expectations offsetting the effects of the parents' expectations. For the BCS70 teenage fatherhood model however, there was little evidence that educational expectations of parents or cohort members were significant - in that model, school orientation was a notably significant predictor, which ties in with previous hypotheses of teenage fatherhood models picking up behavioural and not life course or socio-economic adaptations. Therefore, with respect to the second stated hypothesis, the message is mixed and the evidence inconclusive, although the educational expectations of an adult who is significant in the life of the cohort member, are generally significant predictors of early parenthood.

\section{Cohort effects}

In those groups in which the effect of parental educational expectations could operate differently, 
it could be hypothesised that high parental expectations might be greater among those from higher socio-economic groups. However, no such effect was discovered when testing for interactions between socio-economic variables (tenure, benefits and social class) and parental educational expectations. Direct comparisons between cohorts are hampered by the lack of teacher educational expectations. However, for models of 'early' parenthood, where teacher expectations appeared to play a secondary role in NCDS models, there is remarkable inter-cohort consistency in both the magnitude and direction of the effects of parental educational expectations. Formally testing for cohort effects to investigate the third hypothesis was impossible because of data incompatibility. However, further investigation of parental educational expectations using predicted probabilities (next section) gives weight to the case that these may be of greater influence in the laterborn cohort.

Table 3: Parental Expectations and early parenthood (NCDS cohort: fully adjusted models)

\begin{tabular}{|c|c|c|c|c|c|}
\hline & & $\begin{array}{c}\text { Early Fatherhood (First } \\
25 \%)\end{array}$ & Teenage Fatherhood & $\begin{array}{c}\text { Early Motherhood (First } \\
25 \%)\end{array}$ & Teenage Motherhood \\
\hline \multirow{24}{*}{ 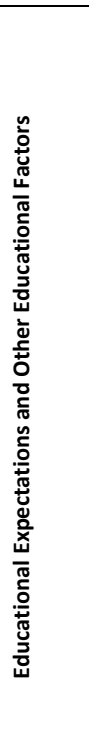 } & \multicolumn{5}{|c|}{ Parental Educational Expectations Age 16 (baseline: Leave School at the minimum) } \\
\hline & Stay until 18 & $0.685^{*}$ & 0.502 & $0.711 *$ & 0.794 \\
\hline & Higher Education & $0.564^{* *}$ & 0.472 & $0.639 *$ & 1.404 \\
\hline & Don't Know/Other & 0.798 & 1.224 & 0.705 & 1.180 \\
\hline & \multicolumn{5}{|c|}{ Teacher Educational Expectations Age 16 (baseline: Leave School at the minimum) } \\
\hline & Stay until 18 & 1.041 & 0.780 & $0.760^{*}$ & $0.571^{*}$ \\
\hline & Higher Education & 0.704 & $0.188 \mathrm{BS}$ & $0.638^{*}$ & $0.345^{*}$ \\
\hline & Don't Know/Other & 0.943 & $0.287^{*}$ & 0.945 & 0.794 \\
\hline & \multicolumn{5}{|c|}{ Cohort Member Educational Expectations Age 16 (baseline: Leave School at the minimum) } \\
\hline & Stay until 18 & 0.566 & 1.040 & 0.785 & 0.906 \\
\hline & Higher Education & 0.636 & 1.490 & 0.714 & 0.718 \\
\hline & Don't Know/Other & 1.014 & 0.616 & 0.984 & 1.203 \\
\hline & \multicolumn{5}{|c|}{ Maths Ability Age 16 (baseline: Lowest Quartile of Ability) } \\
\hline & Quartile 2 & $0.732 *$ & $0.287^{* *}$ & 0.896 & 0.818 \\
\hline & Quartile 3 & $0.751 \mathrm{BS}$ & $0.299 * *$ & $0.719 *$ & 0.743 \\
\hline & Highest Quartile & $0.524^{* *}$ & $0.187^{* *}$ & $0.474^{* *}$ & $0.318^{* *}$ \\
\hline & \multicolumn{5}{|c|}{ Reading Ability Age 16 (baseline: Lowest Quartile of Ability) } \\
\hline & Quartile 2 & 0.928 & 0.913 & 0.837 & 0.866 \\
\hline & Quartile 3 & 0.989 & 1.355 & 0.830 & 0.697 \\
\hline & Highest Quartile & 1.167 & $3.131^{*}$ & $0.640^{* *}$ & 0.822 \\
\hline & \multicolumn{5}{|c|}{ Dislike of School (baseline: Strongly Dislike School) } \\
\hline & Dislike school somewhat & 0.766 & 1.249 & 0.940 & 0.796 \\
\hline & Do not dislike school & 0.840 & 1.163 & 1.081 & 0.885 \\
\hline & Attendance Age 16 & 0.999 & 0.998 & $0.985^{* *}$ & $0.989 * *$ \\
\hline \multirow{10}{*}{ 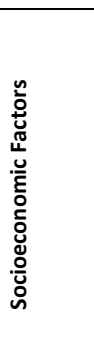 } & \multicolumn{5}{|c|}{ Reports of Father in Non-Manual Social Class during childhood (baseline: All reports in Non-Manual Class) } \\
\hline & Some Reports & $1.407 \mathrm{BS}$ & 0.650 & $1.571 \mathrm{BS}$ & 1.992 \\
\hline & No Reports & 1.546 & 0.831 & 1.522 & 2.157 \\
\hline & \multicolumn{5}{|c|}{ Tenure Reports During Childhood (baseline: All reports of Owner Occupation) } \\
\hline & Some Owner Occ. & 1.259 & 1.158 & $1.406^{*}$ & 1.224 \\
\hline & Only Council & $1.605^{* *}$ & 1.325 & $1.669 * *$ & $1.559 *$ \\
\hline & Some Council & 1.460 & 1.842 & 1.344 & 1.006 \\
\hline & Other & 1.158 & 0.542 & 1.197 & 1.530 \\
\hline & \multicolumn{5}{|c|}{ Receipt of Unemployment/Sickness Benefits Age 16 (baseline: in receipt of benefits) } \\
\hline & $\begin{array}{l}\text { Not in receipt of } \\
\text { benefits }\end{array}$ & 0.979 & 1.248 & 0.908 & 0.967 \\
\hline \multirow{11}{*}{ 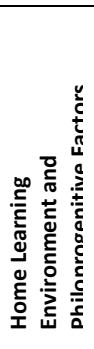 } & \multicolumn{5}{|c|}{ Mother's Interest in Child's Education at Age 16 (baseline: Healthy Interest) } \\
\hline & Some Interest & 1.124 & 1.285 & 1.147 & 1.410 \\
\hline & Unhealthy Interest & 1.242 & 0.926 & $1.602 * *$ & $1.998^{* *}$ \\
\hline & Don't Know & 1.329 & 0.973 & 1.180 & $1.649 \mathrm{BS}$ \\
\hline & \multicolumn{5}{|c|}{ Parental Disciplinarian Index (baseline: very disciplinarian) } \\
\hline & Somewhat & $0.644^{* *}$ & $0.424^{* *}$ & $0.725^{* *}$ & 0.997 \\
\hline & Not Disciplinarian & $0.723^{*}$ & $0.258^{* *}$ & 0.823 & 1.287 \\
\hline & \multicolumn{5}{|c|}{ Philoprogenitive Tendencies (baseline: want a child under 22 years) } \\
\hline & Other response & $0.761 \mathrm{BS}$ & $0.523^{*}$ & $0.684 * *$ & $0.610^{* *}$ \\
\hline & \multicolumn{5}{|c|}{ Mother Stayed in Post-compulsory Education (baseline: did not stay) } \\
\hline & Stayed in Education & 1.080 & 0.633 & 0.953 & 0.792 \\
\hline \multirow{7}{*}{ 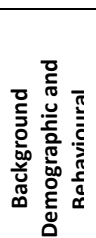 } & \multicolumn{5}{|c|}{ Family Structure Age 16 (baseline: 2 Natural Parents) } \\
\hline & Reconstituted Family & 1.304 & 1.128 & $1.748^{* *}$ & $2.011^{* *}$ \\
\hline & Lone-parent family & 1.010 & 1.333 & 1.107 & 1.314 \\
\hline & \multicolumn{5}{|c|}{ Score for Age 16 Behavioural Component: Disruptive and Aggressive Behaviour (baseline: Lowest Quartile) } \\
\hline & Quartile 2 & $1.336 \mathrm{BS}$ & 1.390 & 1.044 & 1.162 \\
\hline & Quartile 3 & $1.390 *$ & $2.725^{*}$ & $1.332 \mathrm{BS}$ & 1.093 \\
\hline & Highest Quartile & $1.393^{*}$ & $2.326 \mathrm{BS}$ & 1.240 & $1.741^{* *}$ \\
\hline
\end{tabular}




\begin{tabular}{|c|c|c|c|c|}
\hline \multicolumn{5}{|l|}{ Table 3 (Continued) } \\
\hline $\begin{array}{l}\text { Mother's Age at Cohort } \\
\text { Member's Birth }\end{array}$ & 0.996 & 0.973 & $0.984^{*}$ & 0.983 \\
\hline \multicolumn{5}{|c|}{ Region of Residence Age 16 (baseline: Eastern) } \\
\hline London \& South East & 0.866 & 0.394 & 0.887 & 1.290 \\
\hline Northern & 1.144 & 0.877 & 1.305 & 1.263 \\
\hline North Western & 1.054 & 1.239 & 1.078 & 1.604 \\
\hline North Midlands & 0.775 & 1.357 & 0.659 & 1.050 \\
\hline East \& West Riding & 0.959 & 1.727 & $1.605 \mathrm{BS}$ & $2.158^{*}$ \\
\hline Wales & 1.644 BS & 1.097 & 1.330 & 1.486 \\
\hline Scotland & 1.164 & 0.121 & 1.022 & 1.168 \\
\hline $\mathrm{N}$ & 2,288 & 2,521 & 2,834 & 2,834 \\
\hline Pseudo R-squared & 0.122 & 0.200 & 0.172 & 0.166 \\
\hline
\end{tabular}

$* *=p<0.01 *=p<0.05 \quad B S=$ Borderline Significant

\section{Probabilities for Policy}

The results presented in tables 3 and 4 highlight the prominence of educational expectations of a close adult as a predictor of early fertility. This contradicts interventions that have aimed to reduce the level of early pregnancy and early parenthood through focussing solely on structural factors (Social Exclusion Unit 1999; Harden, Brunton et al. 2006; Allen, Bonell et al. 2007). Recently, there has been movement towards interventions that focus on personal development and relationships (Allen, Bonell et al. 2007). The results presented in this section broadly support this change through directly contrasting the effect of changing parental educational expectations, with changing an element of material disadvantage on predicted probabilities in hypothetical situations. These can be interpreted as the percentage predicted to become early parents based on the variation in five characteristics (table 5). These show how the effect of changing educational expectations can offset the effects of material hardship. While the results presented in tables 3 and 4 are the main outputs of this analysis of the effects of parental educational expectations, this section is intended to illuminate the contrast between material and parenting factors.

In the BCS70, this simulation shows that changing educational expectations, from leaving at the minimum age upwards to progressing to higher education, had a larger effect on decreasing the predicted probability of becoming an early parent than changing any other element. This included changing educational ability level, which had the largest effect in decreasing the odds of early parenthood in the NCDS cohort. Philoprogenitive tendencies of the cohort member themselves were also tested, but changing these did not have the same impact on these probabilities as changing parents' educational expectations. 


\begin{tabular}{|c|c|c|c|c|c|}
\hline & Binary Logistic Models: Odds Ratios & $\begin{array}{l}\text { Early Fatherhood } \\
\text { (First 25\%) }\end{array}$ & Teenage Fatherhood & $\begin{array}{l}\text { Early Motherhood } \\
\text { (First 25\%) }\end{array}$ & $\begin{array}{c}\text { Teenage } \\
\text { Motherhood }\end{array}$ \\
\hline \multirow{29}{*}{ 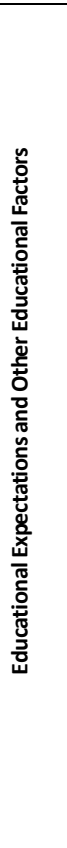 } & \multicolumn{5}{|c|}{ Parental Educational Expectations Age 16 (baseline: Leave School at the minimum) } \\
\hline & Stay until 18 & $0.625^{* *}$ & 0.426 & $0.669 *$ & 0.517 \\
\hline & Higher Education & $0.451^{* *}$ & 0.510 & $0.572^{* *}$ & $0.425 *$ \\
\hline & Don't Know/Other & 1.083 & 0.636 & $0.671^{*}$ & $0.705^{*}$ \\
\hline & Missing & 1.222 & 1.015 & $0.741 \mathrm{BS}$ & 0.707 \\
\hline & \multicolumn{5}{|c|}{ Cohort Member Educational Expectations Age 16 (baseline: Leave School at the minimum) } \\
\hline & Stay until 18 & 0.774 & $0.456^{1}$ & $0.582^{* *}$ & $0.457^{*}$ \\
\hline & Higher Education & $0.550 *$ & & $0.477^{* *}$ & $0.407 \mathrm{BS}$ \\
\hline & Don't Know/Other & 0.613 & & 0.788 & 0.288 \\
\hline & Missing & 0.676 & $0.092^{1}$ & 1.148 & 0.455 \\
\hline & \multicolumn{5}{|c|}{ Maths Ability Age 10 (baseline: Lowest Quartile of Ability) } \\
\hline & Quartile 2 & 0.990 & 0.594 & 0.893 & 1.170 \\
\hline & Quartile 3 & 1.084 & 1.376 & 0.782 & 0.986 \\
\hline & Highest Quartile & 1.236 & 1.537 & 0.765 & 1.189 \\
\hline & \multicolumn{5}{|c|}{ Reading Ability Age 10 (baseline: Lowest Quartile of Ability) } \\
\hline & Quartile 2 & 0.824 & 1.004 & $0.689 *$ & 0.700 \\
\hline & Quartile 3 & 0.797 & 0.710 & $0.720^{*}$ & 0.676 \\
\hline & Highest Quartile & $0.591^{* *}$ & 1.401 & $0.515^{* *}$ & 0.427 \\
\hline & \multicolumn{5}{|c|}{ English Picture Vocabulary Test Age 5 (baseline: Lowest Quartile of Ability) } \\
\hline & Quartile 2 & 1.132 & 1.373 & $0.782 \mathrm{BS}$ & 1.175 \\
\hline & Quartile 3 & 1.022 & 0.724 & 1.003 & 0.746 \\
\hline & Highest Quartile & 0.916 & 0.540 & $0.711^{*}$ & $0.364^{* *}$ \\
\hline & \multicolumn{5}{|l|}{ Dislike of School (baseline: Strongly Dislike School) } \\
\hline & Dislike school somewhat & 0.808 & $0.129 * *$ & 0.754 & 0.690 \\
\hline & Do not dislike school & 0.825 & $0.130 *$ & 0.774 & 0.744 \\
\hline & Missing & 1.285 & 2.276 & 1.289 & 1.065 \\
\hline & \multicolumn{5}{|l|}{ Truancy Age 16 (baseline: Yes, Played Truant) } \\
\hline & No, did not & 0.872 & 0.914 & 0.817 & 0.718 \\
\hline & Missing & 1.544 & 0.820 & 0.915 & 1.155 \\
\hline & Reports of Father in Social Class I and II during & aseline: All reports i & n-Manual Class) & & \\
\hline & Some Reports & 0.805 & 0.425 & 1.367 & 1.161 \\
\hline$\frac{n}{0}$ & No Reports & 0.996 & 0.502 & 1.701 & 1.305 \\
\hline$\underset{\pi}{\pi}$ & Tenure Reports During Childhood (baseline: $A$ & wner Occupation) & & & \\
\hline 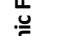 & Some Owner Occ. & 1.120 & 0.636 & $1.593^{* *}$ & 1.291 \\
\hline$\underline{\underline{\varepsilon}}$ & Only Council & $1.556^{* *}$ & 1.275 & $2.168^{* *}$ & $2.164^{* *}$ \\
\hline ర్ & Some Council & 1.471 & 0.946 & 1.549 & 1.717 \\
\hline . & Other & 1.060 & 0.708 & $1.763 *$ & 1.263 \\
\hline & Receipt of Unemployment/Sickness Benefits & ine: in receipt of ben & & & \\
\hline & Not in receipt of benefits & 1.006 & 0.523 & $0.666^{*}$ & $0.610^{*}$ \\
\hline & Mother's Interest in Child's Education at Age & Healthy Interest) & & & \\
\hline & Some Interest & 1.208 & 1.280 & 1.189 & 0.924 \\
\hline & Unhealthy Interest & 1.300 & 0.393 & $2.225^{* *}$ & $2.264^{* *}$ \\
\hline$\stackrel{\pi}{=}$ & Don't Know & $1.706^{* *}$ & 1.015 & 1.209 & 1.037 \\
\hline ¿े & Index of Perceived Parenting Relationship Ag & : Mostly Negative) & & & \\
\hline 흘 & Some Positive & 0.744 & 0.437 & $0.549 * *$ & $0.456^{*}$ \\
\hline 竞: & Mostly Positive & 0.946 & 0.901 & $0.650^{*}$ & $0.531^{*}$ \\
\hline 岕焉 & Missing & 0.693 & 1.448 & $0.460^{*}$ & 0.787 \\
\hline 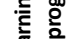 & Philoprogenitive Tendencies: Importance of C & ure Life (baseline: $\Lambda$ & er Very Much) & & \\
\hline ฐ & Matter Somewhat & 1.160 & 1.920 & $0.537^{* *}$ & 0.879 \\
\hline 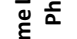 & Don’t Matter & 0.801 & 1.380 & $0.550 * *$ & $0.426^{*}$ \\
\hline & Missing & 0.871 & 0.958 & $0.618^{* *}$ & 0.818 \\
\hline & Mother Stayed in Post-compulsory Education & (not stay) & & & \\
\hline & Stayed in Education & 0.772 & $0.237 \mathrm{BS}$ & 0.855 & 0.875 \\
\hline & Age of Mother at Cohort Member's Birth & $0.942^{* *}$ & 0.977 & $0.962^{* *}$ & $0.966^{*}$ \\
\hline & Score for Age 16 Behavioural Component: Dis & ggressive Behaviou & aseline: Lowest Quartile & & \\
\hline t̀ & Quartile 2 & 0.896 & 1.903 & $1.486 *$ & 1.015 \\
\hline 胥 & Quartile 3 & 1.215 & $2.694 *$ & 1.281 & 1.049 \\
\hline$\overline{\mathrm{d}}$ & Highest Quartile & 1.274 & $5.226 *$ & $1.674^{* *}$ & 2.214 \\
\hline$\underline{\underline{z}}$ & Missing & 0.959 & 4.572 & 1.354 & 1.379 \\
\hline 空 & Family Structure Age 16 (baseline: 2 Natural & & & & \\
\hline $\bar{\Phi}$ & Reconstituted Family & 1.072 & 1.684 & 1.023 & 0.840 \\
\hline 둘 & Lone-parent family & 1.190 & 1.943 & 0.964 & 0.813 \\
\hline . & Region of Residence Age 16 (baseline: East of & & & & \\
\hline 등 & East Midlands & 1.073 & 1.447 & $1.610 \mathrm{BS}$ & 1.665 \\
\hline$\frac{5}{00}$ & London & 0.902 & 2.539 & 0.737 & 0.430 \\
\hline ڤั & North East & 1.034 & 1.120 & 1.126 & 0.744 \\
\hline ఫั & North West & 1.066 & 1.818 & 1.455 & 0.920 \\
\hline 훋 & South East & 1.353 & 0.682 & 1.090 & 0.611 \\
\hline $\bar{\partial}$ & South West & 0.806 & 2.559 & $1.753^{*}$ & 1.041 \\
\hline 总 & West Midlands & 1.166 & 1.739 & 1.382 & 1.299 \\
\hline 莺 & Yorkshire \& Humber & 1.667 & 0.946 & 1.188 & 0.716 \\
\hline & Wales & 1.226 & 3.018 & $1.795^{*}$ & 1.854 \\
\hline & Scotland & 0.921 & 0.175 & 1.045 & 0.779 \\
\hline & $\mathrm{N}$ & 2,410 & 2,410 & 2,647 & 2,647 \\
\hline & Pseudo R-squared & 0.113 & 0.229 & 0.179 & 0.215 \\
\hline & $\begin{array}{l}* *=p<0.01 \quad *=p<0.05 \quad B S=\text { Borderlin } \\
\text { 'post-compulsory education' and 'missing }\end{array}$ & $0.1+5$ & OLLE & . & 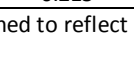 \\
\hline
\end{tabular}


Table 5: Table of predicted probabilities demonstrating the effect of changing educational expectations in two cohorts in hypothetical situations

\begin{tabular}{|c|c|c|c|c|c|c|}
\hline \multicolumn{7}{|c|}{ NCDS } \\
\hline & $\begin{array}{l}\text { Situation 1: } \\
\text { 'Destined' to } \\
\text { early } \\
\text { parenthood }\end{array}$ & $\begin{array}{c}\text { Situation 2: } \\
\text { Changing } \\
\text { Expectations }\end{array}$ & $\begin{array}{l}\text { Situation 3: } \\
\text { Changing } \\
\text { Maths Score }\end{array}$ & $\begin{array}{l}\text { Situation 4: } \\
\text { Changing } \\
\text { Housing } \\
\text { Tenure }\end{array}$ & $\begin{array}{l}\text { Situation 5: } \\
\text { Changing } \\
\text { Social Class } \\
\text { Reports }\end{array}$ & $\begin{array}{l}\text { Situation 6: } \\
\text { Changing } \\
\text { Philoproge- } \\
\text { nitive Report }\end{array}$ \\
\hline $\begin{array}{l}\text { Parental Educational } \\
\text { Expectations Age } 16\end{array}$ & Minimum & 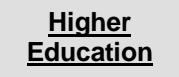 & Minimum & Minimum & Minimum & Minimum \\
\hline Maths Score (16) & Low & Low & High & Low & Low & Low \\
\hline $\begin{array}{l}\text { Tenure Reports } \\
\text { During Childhood }\end{array}$ & $\begin{array}{l}\text { Social } \\
\text { Housing }\end{array}$ & $\begin{array}{l}\text { Social } \\
\text { Housing }\end{array}$ & $\begin{array}{l}\text { Social } \\
\text { Housing }\end{array}$ & Occupation & $\begin{array}{l}\text { Social } \\
\text { Housing }\end{array}$ & $\begin{array}{l}\text { Social } \\
\text { Housing }\end{array}$ \\
\hline $\begin{array}{l}\text { Social Class Reports } \\
\text { During Childhood }\end{array}$ & Lower & Lower & Lower & Lower & Higher & Lower \\
\hline $\begin{array}{l}\text { Early Philopro- } \\
\text { genitive Tendencies }\end{array}$ & High & High & High & High & High & Low \\
\hline $\begin{array}{l}\text { Predicted Probability: } \\
\text { Early Fatherhood }\end{array}$ & $56.3 \%$ & $33.1 \%$ & $35.7 \%$ & $42.1 \%$ & $42.8 \%$ & $35.4 \%$ \\
\hline $\begin{array}{l}\text { Predicted Probability: } \\
\text { Teenage Fatherhood }\end{array}$ & $11.0 \%$ & $4.7 \%$ & $2.2 \%$ & $11.7 \%$ & $9.5 \%$ & $5.0 \%$ \\
\hline $\begin{array}{l}\text { Predicted Probability: } \\
\text { Early Motherhood }\end{array}$ & $54.0 \%$ & $31.4 \%$ & $22.9 \%$ & $38.2 \%$ & $38.9 \%$ & $29.1 \%$ \\
\hline $\begin{array}{l}\text { Predicted Probability: } \\
\text { Teenage Motherhood }\end{array}$ & $29.7 \%$ & $22.7 \%$ & $5.3 \%$ & $14.2 \%$ & $18.7 \%$ & $11.4 \%$ \\
\hline \multicolumn{7}{|c|}{$\begin{array}{l}\text { Key: Parental Expectations Age } 16 \text { (Minimum = Leave at the Minimum Age); Maths Score Age } 16 \text { (Low = Lowest Quartile of } \\
\text { Ability; High = Highest Quartile); Tenure Reports During Childhood (Social Housing = Always in Social Housing; Owner } \\
\text { Occupation = Always in Owner Occupied Housing); Social Class Reports During Childhood (Lower = Always in Manual Social } \\
\text { Class; Higher = Always in Non-Manual Social Class); Philoprogenitive Tendencies (High = Under 22; Low = Over 21) }\end{array}$} \\
\hline \multicolumn{7}{|c|}{ BCS70 } \\
\hline & $\begin{array}{l}\text { Situation 1: } \\
\text { 'Destined' to } \\
\text { early } \\
\text { parenthood }\end{array}$ & $\begin{array}{c}\text { Situation 2: } \\
\text { Changing } \\
\text { Expectations }\end{array}$ & $\begin{array}{c}\text { Situation 3: } \\
\text { Changing } \\
\text { Maths Score }\end{array}$ & $\begin{array}{c}\text { Situation 4: } \\
\text { Changing } \\
\text { Housing } \\
\text { Tenure } \\
\end{array}$ & $\begin{array}{l}\text { Situation 5: } \\
\text { Changing } \\
\text { Social Class } \\
\text { Reports }\end{array}$ & $\begin{array}{l}\text { Situation 6: } \\
\text { Changing } \\
\text { Philoproge- } \\
\text { nitive Report }\end{array}$ \\
\hline $\begin{array}{l}\text { Parental Educational } \\
\text { Expectations Age } 16\end{array}$ & Minimum & Education & Minimum & Minimum & Minimum & Minimum \\
\hline Reading Score (10) & Low & Low & High & Low & Low & Low \\
\hline $\begin{array}{l}\text { Tenure Reports } \\
\text { During Childhood }\end{array}$ & $\begin{array}{l}\text { Social } \\
\text { Housing }\end{array}$ & $\begin{array}{l}\text { Social } \\
\text { Housing }\end{array}$ & $\begin{array}{l}\text { Social } \\
\text { Housing }\end{array}$ & Occupation & $\begin{array}{l}\text { Social } \\
\text { Housing }\end{array}$ & $\begin{array}{l}\text { Social } \\
\text { Housing }\end{array}$ \\
\hline $\begin{array}{l}\text { Social Class Reports } \\
\text { During Childhood }\end{array}$ & Lower & Lower & Lower & Lower & Higher & Lower \\
\hline $\begin{array}{l}\text { Early Philopro- } \\
\text { genitive Tendencies }\end{array}$ & High & High & High & High & High & Low \\
\hline $\begin{array}{l}\text { Predicted Probability: } \\
\text { Early Fatherhood }\end{array}$ & $42.0 \%$ & $19.6 \%$ & $28.0 \%$ & $29.6 \%$ & - & $36.2 \%$ \\
\hline $\begin{array}{l}\text { Predicted Probability: } \\
\text { Teenage Fatherhood }\end{array}$ & $4.8 \%$ & $0.9 \%$ & $4.8 \%$ & $3.3 \%$ & - & $6.7 \%$ \\
\hline $\begin{array}{l}\text { Predicted Probability: } \\
\text { Early Motherhood }\end{array}$ & $63.0 \%$ & $38.7 \%$ & $36.6 \%$ & $40.2 \%$ & - & $50.6 \%$ \\
\hline $\begin{array}{l}\text { Predicted Probability: } \\
\text { Teenage Motherhood }\end{array}$ & $30.2 \%$ & $9.9 \%$ & $10.6 \%$ & $13.3 \%$ & - & $15.4 \%$ \\
\hline $\begin{array}{l}\text { Key: Parental Expectatio } \\
\text { High = Highest Quartile); } \\
\text { Always in Owner Occupi } \\
\text { Always in Social Class I } \\
\text { importance placed on chi }\end{array}$ & $\begin{array}{l}\text { d II); Philoproge } \\
\text { Iren); - = No re }\end{array}$ & $\begin{array}{l}\text { hitive Tendenciє } \\
\text { resentative cas }\end{array}$ & $(\mathrm{High}=\mathrm{High}$ im & $\begin{array}{l}\text { re Age } 16(1 \\
\text { ways in Soc }\end{array}$ & $\begin{array}{l}\text { = Lowest Qua } \\
\text { Housing; Owne } \\
\text { Social Class I } \\
\text { children; Low = }\end{array}$ & $\begin{array}{l}\text { ile of Ability; } \\
\text { Occupation = } \\
\text { nd II; Higher = } \\
\text { Low }\end{array}$ \\
\hline
\end{tabular}




\section{Summary and Conclusions}

\section{Summary and Limitations}

This study investigated the impact of educational expectations as predictors of early parenthood and generally found that these were significant, which supported the underlying hypotheses. Parental educational expectations retain significance, even in the presence of other controlling variables such as educational ability, socio-economic factors, and school and philoprogenitive orientation measures (as displayed in tables 3 and 4), suggesting that these expectations represent more than direct reflections of ability or advantage. Returning to the specific hypotheses:

a) Although the magnitude of the coefficients suggested that higher educational expectations held greater effect in slowing early motherhood than fatherhood, this was not substantiated by testing for interaction effects.

b) Parental expectations were often found to be significant where those of the cohort members were not, although this was not necessarily the case for teachers' expectations. In the NCDS teenage parenthood models, expectations of the teachers were significant and those of the parents were not. In BCS70 models, where information on teachers' expectations of sufficient quality ${ }^{\text {iv }}$ was not available, the cohort members' expectations were significant, although did not offset the effect of the parents' expectations. Overall, the evidence shows that the expectations of significant adults (be they teacher or parent) were predictive of age at first birth.

c) It is difficult to establish that parental educational expectations would increase in significance over time using these data. Certainly in terms of early motherhood, relative to similar socio-economic factors, the effect of parental educational expectations did increase between cohorts (see Table 5). The evidence from these models, suggests that it is increasingly useful to understand early parenthood as being predicted by disadvantaged home learning environments (having parents with low expectations who offer limited scope for life course planning, plus having poor relationships with parents) just as much as it being a consequence of disadvantaged material backgrounds.

There are limitations to these findings. First is the disparity in measurements between cohorts. A second limitation is the absence of further measurements of life course planning: although much of the theoretical basis for this paper is grounded in the notion of life course planning, but only one aspect of life course planning (education) was available. A measurement of parental family building expectations may have been useful. On the other hand, given that education is thought to account for a substantial amount of the variability in fertility patterns (for example Kiernan 1997; Rendall and Smallwood 2003; Lappegard and Ronsen 2005; Rendall, Couet et al. 2005; Smith and Ratcliffe 2009), and that this paper was looking for an overlap between educational and family-building life course planning, this is not considered a drawback. Similarly, this paper is theoretically grounded in the assumption that these expectations reflect a component of planning and are not solely a reflection of current behaviour. At any rate, their discovery as predictors of early parenthood does contribute to the field, and qualitative research may illuminate this issue further. The absence of other factors including partnership, housing, and employment status is a further limitation as the models do not explicitly recognise that parenthood is symbiotic with other life course events. However, their inclusion would go beyond the intention of the present analysis, which was to examine childhood predictors of early fertility. Furthermore, the concern was to look at all forms of early parenthood (married, unmarried etc) jointly and not to distinguish different circumstances.

A more substantial concern is the two-fold reduction of the sample. Firstly, the effect of missing data reduced the sample size, and is a caveat of the results, as the sample under-represents those from disadvantaged backgrounds (not shown). In addition, since the sample was further restricted, as the measures of early parenthood only began at age $17 \frac{1}{2}$ years, there are concerns about establishing causality. This restriction resulted in a small number of early parents being excluded from models, which did not substantively impact on the results. Additionally, while 
$171 / 2$ was chosen as a point at which issues of causality were reduced, they may not necessarily have been completely eliminated, particularly in the context of 'life course planning'. Plans may have been 'set in motion' at the time of questioning, for a small number, so it was not so much the planning, as the implementation of the plan, that was being detected, and this is a further caveat on these results.

\section{Conclusions and Policy Implications}

Educational expectations held by adult figures are found to be highly influential over the odds of entering first parenthood early. The evidence in table 5 shows that raising educational expectations can have the same impact as altering an element of disadvantage. Opportunity costs have usually been regarded as the calculation of the minimum impact of wage penalties and missed career opportunities resulting from motherhood. Assortative mating is one likely mechanism by which these costs impact on male fertility patterns. The results in this paper suggest that these calculations are not based on educational ability alone. Parents' or teachers' expectation of a young person's entry to higher education was protective even when educational test score achievements, school orientation, cohort members' expectation and socioeconomic background suggested that this expectation was likely to remain unfulfilled. In other words, parental educational expectations help those usually considered predestined for early parenthood through having low opportunity costs, to postpone.

The results demonstrate that asking about the future and particularly educational expectations, can aid the identification of those who are likely to become early parents. This is a simple but often overlooked concept. Young people have strong ideas about their life course - that overlap somewhat with aspirations - but these are likely to be shaped, changed or reinforced by the adult figures around them. Evidence in this paper suggests that adult expectations are more predictive than those of the children. Raising expectations, even from leaving school at the minimum age to leaving at age 18 reduces the probability of entering early parenthood. These results suggest that more emphasis should be placed on planning and expectations involving young people, their parents and their teachers, and that further research may need to be conducted into the dynamics of these relationships.

For young people for whom formal higher education may not be suitable, greater parental knowledge about vocational education options might increase educational expectations and lead to a decrease in early parenthood. Altering expectations may not be insurmountable. Interventions aimed at raising aspirations show the efficacy of the provision of parenting experts, empowering parents in their children's education through becoming school governors, and providing financial information, advice and guidance on the costs and benefits of higher education through 'money guidance pathfinder' schemes (Cabinet Office 2008). Such actions may also alter parents' interest in their children's education, which was also found to be a significant predictor of early motherhood.

A further implication of the results is the fact that male fertility histories were significantly influenced by educational expectations. While the opportunity cost pathway is usually applied only to women, this paper suggests that males are influenced by factors that are usually included in hypothesised calculations of opportunity costs, and they are influenced by the perception of opportunity costs, adding another dimension to assortative mating theories.

Finally, the findings in this paper could not have been replicated using a different study design because only a longitudinal design could match expectations with adult outcomes. It is probable that fertility is not alone as an adult outcome predicted by life course expectations. Other research has looked at expectations and the relationship with attainment and occupation, but is limited in terms of other dimensions such as family building (Schoon 2006; Schoon, Martin et al. 2007; Flouri and Hawkes 2008). Future research both in terms of prediction and intervention could usefully analyse whether the relationship between expectations and other domains, such as poor housing, or low life satisfaction can be utilised to prevent cycles of disadvantage.

This is one of the first studies to present quantitative evidence of the role of parental educational expectations as predictors of early parenthood, and to examine their role alongside the expectations of other actors in cohort members' lives. The title of this paper referred to 'pushy' parents - in this context, being 'pushy' through having higher expectations was not a negative trait. On the other hand, as has been emphasised, early parenthood itself is not necessarily negative. For many it may well be a desired state. This paper shows that the seeds of this ambition are sowed in part through the educational expectations of parents. 


\section{Acknowledgements}

This paper was originally presented as a winning entry to the Neville Butler Memorial Prize. I received very constructive and helpful feedback from the competition judges, editors, and from John Bynner in particular, in subsequently developing this paper. The analyses presented in this paper are based in part upon analysis submitted for my PhD and I am indebted to Heather Joshi and Jane Elliot for all their assistance and encouragement during this time. I am also grateful to Ruth Lupton and Richard Wiggins for recent guidance with this paper. Wendy Sigle-Rushton has also been a source of very valuable assistance and advice in this process as has Leon Smith in providing editorial assistance. Finally, the cohort studies are dependent on the voluntary participation of the cohort members and the work of the Centre for Longitudinal Studies (Institute of Education) in maintaining these studies, and I am grateful to both.

\section{References}

Allen, E., Bonell, C., Strange, V., Copas, A., Stephenson, J., Johnson, A. M., \& Oakley, A. (2007) Does the UK government's teenage pregnancy strategy deal with the correct risk factors? Findings from a secondary analysis of data from a randomised trial of sex education and their implications for policy. Journal of Epidemiology and Community Health, 61, 21-27.

Arai, L. (2003) Low expectations, sexual attitudes and knowledge: explaining teenage pregnancy and fertility in English communities. Insights from qualitative research. Sociological Review, 51, 199-217.

Arai, L. (2007) Peer and neighbourhood influences on teenage pregnancy and fertility: Qualitative findings from research in English communities. Health \& Place, 13, 87-98.

Becker, G. S. (1991) A Treatise on the Family. Cambridge, Massachusetts: Harvard University Press.

Bond, R., \& Saunders, P. (1999) Routes of success: influences on the occupational attainment of young British males. British Journal of Sociology, 50, 216-248.

Burchardt, T., Le Grande, J., \& Piachaud, D. (2002) Degrees of exclusion: developing a dynamic, multidimensional measure. In J. Hills, J. Le Grande \& D. Piachaud (Eds.), Understanding Social Exclusion. Oxford: Oxford University Press.

Bynner, J., \& Joshi, H. (2007) Building the evidence base from longitudinal data: the aims, content and achievements of the British Birth Cohort Studies. Innovation: The European Journal of Social Science Research, 20, 159-179.

Cabinet Office. (2008) Aspiration and attainment amongst young people in deprived communities. London: Cabinet Office.

Casanova, P. F., García-Linares, M. C., de la Torre, M. J., \& de la Villa Carpio, M. (2005) Influence of family and socio-demographic variables on students with low academic achievement. Educational Psychology, 25, 423-435.

Driscoll, A. K., Sugland, B. W., Manlove, J., \& Papillo, A. R. (2005) Community opportunity, perceptions of opportunity, and the odds of an adolescent birth. Youth \& Society, 37, 33-61.

Duncan, S. (2007) What's the problem with teenage parents? And what's the problem with policy? Critical Social Policy, 27, 307-334.

Edwards, M. E. (2002) Education and Occupations: Reexamining the conventional wisdom about later first births among American mothers. Sociological Forum, 17, 423-443.

Ekert-Jaffe, O., Joshi, H., Lynch, K., Mougin, R., Rendall, M. S., \& Shapiro, D. (2002) Fertility, timing of births and socio-economic status in France and Britain: social policies and occupational polarization. Population (English edition), 57, 475-507.

Elliott, J., \& Shepherd, P. (2006) Cohort profile: 1970 British Birth Cohort (BCS70). International Journal of Epidemiology, 35, 836-843.

Ermisch, J., \& Pevalin, D. (2003) Who has a child as a teenager? (No. 30). Colchester: Institute for Social and Economic Research: University of Essex.

Feinstein, L., Duckworth, K., \& Sabates, R. (2008) Education and the family: passing success across the generations. London: Routledge.

Ferri, E., Bynner, J., \& Wadsworth, M. (2003) Changing Britain, changing lives: three generations at the turn of the century. London: Institute of Education, University of London.

Ferri, E., \& Smith, K. (2003) Partnerships and parenthood. In E. Ferri, J. Bynner \& M. Wadsworth (Eds.), Changing Britain, changing lives: three generations at the turn of the century. London: Institute of Education.

Flouri, E. (2006) Parental interest in children's education, children's self-esteem and locus of control, and later educational attainment: Twenty-six years follow-up of the 1970 British Birth Cohort. British Journal of Educational Psychology, 76, 41-55.

Flouri, E., \& Hawkes, D. (2008) Ambitious mothers--successful daughters: mothers' early expectations for children's education and children's earnings and sense of control in adult life. British Journal of Educational Psychology, 78, 411-433. 
Furstenberg, F. F. (2007) Destinies of the disadvantaged: he politics of teen childbearing. New York: Russell Sage Foundation.

Geronimus, A. (2003). Damned if you do: culture, identity, privilege, and teenage childbearing in the United States. Social Science \& Medicine, 57, 881-893.

Goldenberg, C., Gallimore, R., Reese, L., \& Garnier, H. (2001) Cause or effect? A longitudinal study of immigrant Latino parents' aspirations and expectations, and their children's school performance. American Educational Research Journal, 38, 547-582.

Golding, J. (1975) The 1970 Birth Cohort. Bristol: Institute of Child Health: University of Bristol.

Goldstein, H. (2009) Handling attrition and non-response in longitudinal data. Longitudinal \& Life Course Studies, 1, 63-72.

Goodman, A., \& Butler, N. (2005) BCS70 - The 1970 British Cohort Study: the sixteen-year follow-up. London: Social Statistics Research Unit: City University.

Goyette, K. (2008) College for some to college for all: social background, occupational expectations, and educational expectations over time. Social Science Research, 37, 461-484.

Greene, M. E., \& Biddlecom, A. E. (2000) Absent and problematic men: demographic accounts of male reproductive histories. Population and Development Review, 26, 81-115.

Gustafsson, S. (2001) Optimal age at motherhood. theoretical and empirical considerations on postponement of maternity in Europe. Journal of Population Economics, 14, 225-247.

Hadfield, L., Rudoe, N., \& Sanderson-Mann, J. (2007) Motherhood, choice and the British media: a time to reflect. Gender and Education, 19, 255-263.

Harden, A., Brunton, G., Fletcher, A., Oakley, A., Burchett, H., \& Backhans, M. (2006) Young people, pregnancy and social exclusion: a systematic synthesis of research evidence to identify effective, appropriate and promising approaches for prevention and support. London: The Evidence for Policy and Practice Information and Co-ordinating Centre (EPPI-Centre), Social Science Research Unit, Institute of Education, University of London.

Hawkes, D., Joshi, H., \& Ward, K. (2004) Working Paper 6 - Unequal entry into motherhood and unequal starts in life: evidence from the first survey of the UK Millennium Cohort (Working Paper). London: Centre for Longitudinal Studies, Institute of Education: University of London.

Hobcraft, J. (2008). The timing and partnership context of becoming a parent: cohort and gender commonalities and differences in childhood antecedents. Demographic Research, 19, 1281-1322.

Hobcraft, J., \& Kiernan, K. (2001) Childhood poverty, early motherhood and adult exclusion. British Journal of Sociology, 52, 495-517.

Hynes, K., Joyner, K., Peters, H. E., \& DeLeone, F. Y. (2008) The transition to early fatherhood: national estimates based on multiple surveys. Demographic Research, 18, 337-376.

Imamura, M., Tucker, J., Hannaford, P., Oliveira da Silva, M., Astin, M., Wyness, L., Bloemenkamp, K., Jahn, A., Karro, H., Olsen, J. \& Temmermen, M. (2007) Factors associated with teenage pregnancy in the European Union countries: a systematic review. European Journal of Public Health, 17, 630-636.

Joshi, H. (1998) The opportunity costs of childbearing: more than mothers' business. Journal of Population Economics, 11, 161-183.

Joshi, H. (2002) Production, reproduction, and education: women, children and work in a British perspective. Population and Development Review, 28, 445-474.

Kendall, C., Afable-Munsuz, A., Speizer, I., Avery, A., Schmidt, N., \& Santelli, J. (2005). Understanding pregnancy in a population of inner city women in New Orleans - results of qualitative research. Social Science \& Medicine, 60, 297-311.

Kiernan, K., \& Diamond, I. (1983) The age at which childbearing starts - a longitudinal study. Population Studies, 37, 363-380.

Kiernan, K. E. (1997) Becoming a young parent: a longitudinal study of associated factors. The British Journal of Sociology, 48, 406-428.

Kiernan, K. E., \& Cherlin, A. J. (1999) Parental divorce and partnership dissolution in adulthood: evidence from a British cohort study. Population Studies-a Journal of Demography, 53, 39-48.

Kneale, D. (2009a) Early parenthood: definition and prediction in two British cohorts. In J. Stillwell, E. Coast \& D. Kneale (Eds.), Fertility living arrangements, care and mobility. Dordrecht: Springer.

Kneale, D. (2009b) Pathways to parenthood: exploring the influence of context as a predictor of early parenthood. Institute of Education: University of London, London.

Kneale, D., \& Joshi, H. (2008) Postponement and childlessness - evidence from two British cohorts. Demographic Research, 19), 1935-1968.

Lappegard, T., \& Ronsen, M. (2005) The multifaceted impact of education on entry into motherhood. European Journal of Population, 21, 31-49.

Lupton, R., \& Kintrea, K. (2008) Community-level influences on educational attainment: a review for the Social Exclusion Taskforce. London School of Economics \& University of Glasgow.

Lupton, R., Tunstall, R., Sigle-Rushton, W., Obolenskaya, P., Sabates, R., Meschi, E., Kneale, D. \& Salter, E. (2009) Growing up in social housing: a profile of four generations from 1946 to the present day. York: Joseph Rowntree Foundation.

Makepeace, G., Dolton, P., Woods, L., Joshi, H., \& Galinda-Rueda, F. (2003) From school to the labour market. In E. Ferri, J. Bynner \& M. Wadsworth (Eds.), Changing Britain, changing lives; three generations at the turn of the century. London: Bedford Way Papers: Institute of Education, University of London.

Meade, C. S., Kershaw, T. S., \& Ickovics, J. R. (2008) The intergenerational cycle of teenage motherhood: an ecological approach. Health Psychology, 27, 419-429. 
Mensah, F. K., \& Hobcraft, J. (2008) Childhood deprivation, health and development: associations with adult health in the 1958 and 1970 birth cohort studies. Journal of Epidemiology and Community Health, 62, 599-606.

Morrison Gutman, L., \& Akerman, R. (2008) Determinants of aspirations. London: Centre for Research on the Wider Benefits of Learning, Institute of Education, University of London.

Plewis, I., Calderwood, L., Hawkes, D., \& Nathan, G. (2004) National Child Development Study and 1970 British Cohort Study Technical Report: Changes in the NCDS and BCS70 populations and samples over time. London: Centre for Longitudinal Studies, Institute of Education, University of London.

Power, C., \& Elliott, J. (2006) Cohort profile: 1958 British birth cohort (National Child Development Study). International Journal of Epidemiology, 35, 34-41.

Qian, Z. (1998). Changes in assortative mating: the impact of age and education, 1970-1990 Demography, 35, 279-292.

Rendall, M. S., Clarke, L., Peters, H. E., Ranjit, N., \& Verropoulou, G. (1999) Incomplete reporting of men's fertility in the United States and Britain: a research note. Demography, 36, 135-144.

Rendall, M. S., Couet, C., Lappegard, T., Robert-Bobee, I., Ronsen, M., \& Smallwood, S. (2005) First birth by age and education in Britain, France and Norway. Population Trends, 121, 27-34.

Rendall, M. S., \& Smallwood, S. (2003) Higher qualifications, first birth timing and further childbearing in England and Wales. Population Trends, (111), 18-27.

Reynolds, J. R., \& Woodham Burge, S. (2008) Educational expectations and the rise in women's postsecondary attainments Social Science Research, 37, 485-499.

Robson, K., \& Berthoud, R. (2006) Age at first birth and disadvantage among ethnic groups in Britain. Ethnic and Racial Studies, 29, 153-172.

Russell, S. (2002) Childhood developmental risk for teen childbearing in Britain. Journal of Research on Adolescence, 12, 305-324.

Rutter, M. (1967) A children's behaviour questionnaire for completion by children: preliminary findings. Journal of Child Psychology and Psychiatry, 8, 1-11.

Schoeni, R., \& Ross, K. (2004) Material assistance received from families during transition to adulthood. In R. A. Settersten, F. F. Furstenberg \& R. G. Rumbaut (Eds.), On the frontier of adulthood: theory, research and public policy. Chicago: University of Chicago.

Schoon, I. (2006) Risk and resilience: adaptations in changing times. Cambridge, UK: Cambridge University Press.

Schoon, I. (2010) High hopes in a changing world: social disadvantage, educational expectations, and occupational attainment in three British Cohort Studies. In C. Raffo, A. Dyson, H. Gunter, D. Hall, L. Jones \& A. Kalambouka (Eds.), Education and poverty in affluent countries. London: Routledge.

Schoon, I., Martin, P., \& Ross, A. (2007) Career transitions in times of social change. his and her story. Journal of Vocational Behavior, 70, 78-96.

Sigle-Rushton, W. (2005) Intergenerational and life-course transmission of social exclusion in the 1970 British Cohort Study. London: Centre for the Analysis of Social Exclusion (CASE), London School of Economics and Political Science.

Sigle-Rushton, W. (2005) Young fatherhood and subsequent disadvantage in the United Kingdom. Journal of Marriage and the Family, 67, 735-753.

Smith, L., Adler, N., \& Tschann, J. (1999) Underreporting sensitive behaviors: the case of young women's willingness to report abortion. Health Psychology, 18, 37-43.

Smith, S., \& Ratcliffe, A. (2009) Women's education and childbearing: a growing divide. In J. Stillwell, E. Coast \& D. Kneale (Eds.), Fertility, living arrangements, migration and care. Dordrecht: Springer.

Social Exclusion Unit. (1999) Teenage pregnancy. London: Social Exclusion Unit.

Sweeny, M. M., \& Cancian, M. (2004) The changing importance of white women's economic prospects for assortative mating. Journal of Marriage and Family, 66, 1015-1028.

UNICEF. (2007) Child poverty in perspective: an overview of child well-being in rich countries. Florence: UNICEF Innocenti Research Centre.

\section{Endnotes}

\footnotetext{
'The father's interest was also measured but was largely insignificant alongside the mother's. Over $50 \%$ of responses were missing at age 16 for BCS70 and therefore reports from this age are not used.

ii The results of the likelihood ratio tests and Hosmer-Lemeshow tests are not shown.

iii Those who responded that they either expected their child to leave at the minimum age, to stay on until 18 or to progress to higher education.
}

${ }^{\text {iv }}$ Over $50 \%$ of observations were missing. 